\title{
Cyclosporine-A induced nephrotoxicity in male and female rats: Is zinc a suitable protective supplement?
}

\author{
Samira Choopani ${ }^{1}$, Sayyedehnikta Kasaei ${ }^{1}$, Ardeshir Talebi ${ }^{1,2}$, Mojgan Mortazavi ${ }^{3}$, Yousef Gheisari ${ }^{4}$, \\ Mohammad Matinfar ${ }^{3}$, Mehdi Nematbakhsh ${ }^{1,5,6, *}$
}

\section{${ }^{1}$ Water and Electrolytes Research Center, Isfahan University of Medical Sciences, Isfahan, Iran \\ ${ }^{2}$ Department of Clinical Pathology, Isfahan University of Medical Sciences, Isfahan, Iran \\ ${ }^{3}$ Isfahan Kidney diseases Research Center, Isfahan University of Medical Sciences, Isfahan, Iran}

${ }^{4}$ Department of Genetics and Molecular Biology, Isfahan University of Medical Sciences, Isfahan, Iran

${ }^{5}$ Department of Physiology, Isfahan University of Medical Sciences, Isfahan, Iran

${ }^{6}$ Isfahan MN Institute of Basic and Applied Sciences Research, Isfahan, Iran

\section{Correspondence}

Mehdi Nematbakhsh, Water and Electrolytes Research Center, Isfahan University of Medical Sciences, Isfahan, Iran

Department of Physiology, Isfahan University of Medical Sciences, Isfahan, Iran

Isfahan MN Institute of Basic and Applied Sciences Research, Isfahan, Iran

Email: nematbakhsh@med.mui.ac.ir

History

- Received: 09 October 2018

- Accepted: 29 November 2018

- Published: 25 December 2018

DOI :

https://doi.org/10.15419/bmrat.v5i12.507

\section{Check for updates}

\section{Copyright}

(c) Biomedpress. This is an openaccess article distributed under the terms of the Creative Commons Attribution 4.0 International license.

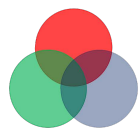

\begin{abstract}
Background: Cyclosporine (CYC) is an immunosuppressant drug used widely in kidney transplant patient. The major side effect of CYC is nephrotoxicity. In this study, three different doses of CYC alone or accompanied with zinc (Zn) supplement were administrated in male and female rats to determine the kidney tissue damages and functions. Methods: Male and female rats were treated with 10,50 or $100 \mathrm{mg} / \mathrm{kg} /$ day of CYC alone or accompanied with $10 \mathrm{mg} / \mathrm{kg} /$ day of Zn sulfate for 10 days. The parameters related to renal function were determined and the kidney tissues were subjected to histological evaluation. Results: All male and female animals were treated with high dose CYC (100 mg/kg/day) alone or accompanied with Zn supplement during the experiment. The data obtained for the serum levels of creatinine $(\mathrm{Cr})$ and blood urea nitrogen/ $\mathrm{Cr}$ ratio, clearance of $\mathrm{Cr}$, kidney weight (KW), sodium (Na) filtration rate, Na excretion rate and Na excretion fraction (\%) in surviving animals suggest a role of gender in the variation of these factors. The kidney tissue damage score (KTDS) was increased as the dosage of CYC was elevated, and the Zn supplement attenuated the KTDS in animals treated with low dose CYC (10 mg/kg/day). Conclusion: The CYC-induced nephrotoxicity may be gender-related, and the $10 \mathrm{mg} / \mathrm{kg}$ dose of $\mathrm{Zn}$ sulphate as a supplement may possibly prevent the induced nephrotoxicity in males due to its antioxidant effects.
\end{abstract}

Key words: Cyclosporine, Gender, Nephrotoxicity, Renal function, Zinc

\section{INTRODUCTION}

Calcineurin inhibitors (CNIs) include cyclosporine (CYC), tacrolimus, voclosporin and pimecrolimus. Patients with organ transplant usually receive CYC and tacrolimus as immunosuppressant agents to avoid organ transplant rejection, but these drugs can cause acute and chronic nephrotoxicity ${ }^{1}$. Among them, the major adverse effects of CYC are nephrotoxicity, hepatoxicity, hypertension and risk of malignancy, thereby limiting its clinical use. The optimal use dosage of CYC for patient monitoring is one of the major difficulties in the clinic, thus dose adjustment strategy has been suggested for CYC ther$\mathrm{apy}^{2}$. In addition, many research studies have been conducted to suggest supplemental agents to confer additional protection for the kidney against CYCinduced toxicity. These supplemental agents may include herbal drugs ${ }^{3-5}$, endothelin-1 receptor antagonists $^{6}$, antihypertensive drugs or $\beta$-blockers ${ }^{7-9}$, NADPH oxidase activity inhibitor ${ }^{10}$, antioxidants ${ }^{11}$, omega-3 fatty acids ${ }^{12}$, apelin peptide ${ }^{13}$, and/or renin inhibitor $^{14}$.

Gender and sex hormones are also important factors that influence the effects of CYC ${ }^{15-19}$. CYC-mediated side effects may be gender-related in kidney ${ }^{20}$ and heart $^{21}$. El-Bassossy and Eid reported that 21 days of CYC treatment in rats led to sex-related nephrotoxicity due to different responses to inflammatory factors ${ }^{20}$. Until now, the role of gender or sex hormones in kidney toxicity induced by other drugs, such as cisplatin and gentamicin, have been documented ${ }^{22-33}$, although their mechanisms have not been completely understood.

In addition, the antioxidant supplements, such as zinc (Zn), have been widely used in laboratory research to protect the kidney against injury ${ }^{34-42}$. It seems that the administration of this trace element $\mathrm{Zn}$ could be considered as a safe protective agent for transplant patients. Therefore, in the current study, we evaluated three different doses of CYC, alone or accompanied with $\mathrm{Zn}$ supplement; moreover, kidney tissue damages and functions were investigated.

\section{METHODS}

\section{Animals}

This research was conducted on 110 male $(n=55$, $268 \pm 4 \mathrm{~g})$ and female $(\mathrm{n}=55,209 \pm 2 \mathrm{~g})$ Wistar rats split among 14 experimental groups. The protocol for our study was approved by the Ethics Committee of Isfahan University of Medical Sciences 
(IR.MUI.REC.1397.2.053).

\section{Experimental group design}

Group 1 (n=8; 252 $\pm \mathbf{1 1 g}$ ): male rats treated with vehicle (sesame oil) as a solvent for CYC.

Groups 2, 3, and 4 (n=8 per group; $280 \pm 11$, $256 \pm 15 \mathrm{~g}$, and $282 \pm 7 \mathrm{~g}$, respectively): male rats treated with 10,50 and $100 \mathrm{mg} / \mathrm{kg} /$ day of CYC dissolved in sesame oil, respectively.

Groups 5, 6, and 7 ( $n=8$ per group except group $5(\mathrm{n}=7) ; 266 \pm 8 \mathrm{~g}, 272 \pm 11 \mathrm{~g}$, and $266 \pm 13 \mathrm{~g}$, respectively): male rats co-treated with 10,50 and 100 $\mathrm{mg} / \mathrm{kg} /$ day of CYC dissolved in sesame oil, respectively, plus $10 \mathrm{mg} / \mathrm{kg} /$ day of $\mathrm{Zn}$ sulfate as a supplement.

Groups 8-14 ( $n=8$ per group except group $11(n=7)$; 205 $\pm 5 \mathrm{~g}, \quad 204 \pm 6 \mathrm{~g}, \quad 211 \pm 6 \mathrm{~g}, \quad 217 \pm 10 \mathrm{~g}, \quad 211 \pm 4 \mathrm{~g}$, $205 \pm 6 \mathrm{~g}$, and $210 \pm 7 \mathrm{~g}$, respectively): female rats were given the same regimen as male rats in Groups 1-7. The treatment duration for each group was 10 days.

\section{Drugs}

CYC was purchased from Zahravi Pharm Co. (Tabriz, Iran). Each capsule of CYC contains $100 \mathrm{mg}$ of CYC. To prepare the desired concentrations, the drug was dissolved in sesame oil (Barij Esans Co, Isfahan, Iran). The $\mathrm{Zn}$ sulfate used in this study was from BDH Co. (London, England) with 99\% purity.

\section{Treatments}

Based on the design of the experimental groups, CYC was administrated daily by subcutaneous injection and for 10 consecutive days. The $\mathrm{Zn}$ sulfate was also given daily by intra-peritoneal injection (i.p.) for 10 consecutive days based on body weight.

\section{Measurements}

Mortality rate for each group was recorded daily, and the remaining surviving animals (until the $11^{\text {th }}$ day) were subjected to placement in metabolic cages for 3 hour urine collection. The volume of urine was determined by scaled micro tube. Finally, the blood samples were obtained and the animals were sacrificed humanely. Then, kidney tissue was fixed in $10 \%$ formalin to perform histological evaluation using $\mathrm{H} \& \mathrm{E}$ staining. The tissue damage in the stained tissue (as kidney tissues damage score; KTDS) was scored by a pathologist who was blinded to the study protocol. The score was assigned from 1 to 4 based on intensity of tissue damage while zero was considered as normal. The intensity of tissue damage was considered based on criteria of vacuolization, dilatation, hyaline cast, debris or degeneration.

The levels of blood urea nitrogen (BUN) and creatinine $(\mathrm{Cr})$ were determined using quantitative diagnostic kits (Pars Azmoon, Iran) by automatic analyzer RA-1000 (Technicon, Ireland). The levels of sodium (Na) in serum and urine were determined by flame photometer assay using Flam Fp20 Model (Seac Co, Italy). The $\mathrm{Cr}$ clearance ( $\mathrm{ClCr}$ ) was calculated by the clearance formula: $\mathrm{ClCr}=$ urine flow $(\mathrm{UF})^{\star}$ urine $\mathrm{Cr}$ level/ serum Cr level.

\section{Statistical Analysis}

Data were reported as mean \pm SEM. The one way ANOVA and Student's t-test for quantitative data were used to compare the measured parameters between the groups. The Kruskal Wallis $\mathrm{H}$ and Mann-Whitney tests were applied to compare the histology findings between the groups. Indeed, p-value $<0.05$ was considered statistically significant.

\section{RESULTS}

\section{Animal survival and weight change}

The data for animal survival time were tabulated in Tables 1 and 2. The entire male and female animals treated with high dose CYC (100 mg/kg/day) expired during the experiment and no animals survived on the last day of experiment ( $11^{\text {th }}$ day- sacrifice day). The survival time of male rats in groups 1-7 were 11.0 \pm 0.0 , $10.8 \pm 0.2,10.6 \pm 0.3,4.8 \pm 0.4,11.0 \pm 0.0,9.6 \pm 0.8$ and $3.7 \pm 0.5$ days $(\mathrm{P}<0.0001)$, while the survival time of female rats in groups 8-14 were $11.0 \pm 0.0,11.0 \pm 0.0$, $10.5 \pm 0.3,7.0 \pm 0.7,11.0 \pm 0.0,9.7 \pm 0.8$ and $5.1 \pm 0.4$ days $(\mathrm{P}<0.0001)$, respectively (Tables 1 and 2$)$.

In male rats, the percentage change of weight of animals in the CYC alone treatment groups were significantly less than vehicle-treated group (vehicle: $11.52 \pm 2.3 \%$, CYC 10: $1 \pm 4.3 \%$, CYC 50: $1 \pm 4.5 \%, \mathrm{P}<0.05)$. In addition, the percentage change of weight loss in male rats co-treated with CYC (50 $\mathrm{mg} / \mathrm{kg} /$ day) and $\mathrm{Zn}(-16.15 \pm 1.9 \%)$ was significantly greater than CYC $(50 \mathrm{mg} / \mathrm{kg})$ alone treated group ($1 \pm 4.50 \%)(\mathrm{P}<0.05)$. However, in female rats a greater percentage of weight loss was observed in CYC (50 $\mathrm{mg} / \mathrm{kg} /$ day), with or without $\mathrm{Zn}$, treatment groups ($14.39 \pm 1.89$ and $-15.50 \pm 2.69 \%, \mathrm{P}<0.001$ ) (Figure 1). CYC alone administration increased the kidney weight (KW) normalized to body weight (BW) in male rats significantly when compared with vehicle group (vehicle; 0.67 \pm 0.02, CYC 10: $0.72 \pm 0.01 \mathrm{~g} / 100$ g BW, CYC 50: 0.76 \pm 0.02 g/ 100 g BW, $\mathrm{P}<0.05$ ), while addition of $\mathrm{Zn}$ supplement did not alter $\mathrm{KW}$ towards 
Table 1: The mean values of survival time for each group of male and female rats during the experiment

\begin{tabular}{|c|c|c|c|c|c|c|c|c|c|c|c|c|c|c|}
\hline \multirow[t]{2}{*}{ Group } & \multirow[t]{2}{*}{$\mathbf{n}$} & \multicolumn{2}{|l|}{ Treatment/Day } & \multicolumn{8}{|c|}{ Number of Death Animals (Male) } & \multirow{2}{*}{\multicolumn{2}{|c|}{ Survived }} & \multirow{2}{*}{$\begin{array}{c}\text { Survival Time } \\
\text { (day) }\end{array}$} \\
\hline & & & 1 & 2 & 3 & 4 & 5 & 6 & 7 & 8 & 9 & & & \\
\hline 1 & 8 & Vehicle & - & - & - & - & - & - & - & - & - & - & 8 & $11.0 \pm 0.0$ \\
\hline 2 & 8 & CYC10 & - & - & - & - & - & - & - & - & 1 & - & 7 & $10.8 \pm 0.2$ \\
\hline 3 & 8 & CYC50 & - & - & - & - & - & - & - & - & 1 & 1 & 6 & $10.6 \pm 0.3$ \\
\hline 4 & 8 & CYC100 & - & - & - & 4 & 3 & - & 1 & - & - & - & 0 & $4.8 \pm 0.4^{a, b, c}$ \\
\hline 5 & 7 & $\mathrm{CYC} 10+\mathrm{Zn}$ & - & - & - & - & - & - & - & - & - & - & 7 & $11.0 \pm 0.0$ \\
\hline 6 & 8 & $\mathrm{CYC} 50+\mathrm{Zn}$ & - & - & - & - & 1 & - & - & 1 & 1 & - & 5 & $9.6 \pm 0.8$ \\
\hline 7 & 8 & $\mathrm{CYC} 100+\mathrm{Zn}$ & - & 1 & 4 & - & 2 & 1 & - & - & - & - & 0 & $3.7 \pm 0.5$ \\
\hline P Krusk & l-h & llis $\mathrm{H}$ (between $\mathrm{g}$ & oup & $1-4)$ & & & & & & & & & & $\mathrm{P}<0.0001$ \\
\hline
\end{tabular}

Table 2: The mean values of survival time for each group of male and female rats during the experiment (continued)

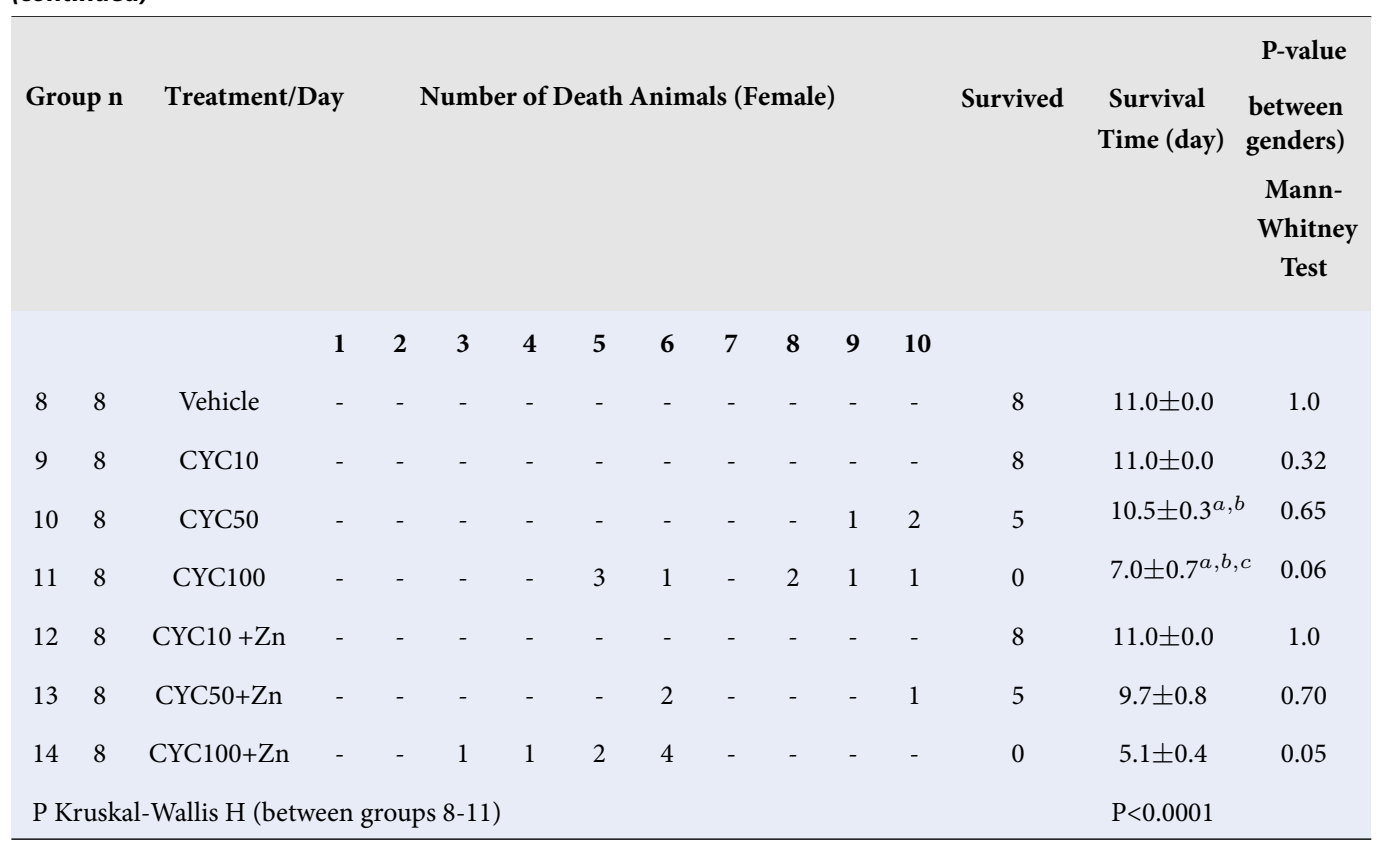

CYC10, CYC50 and CYC100 represent thegroups treated with 10,50 and $100 \mathrm{mg} / \mathrm{kg} /$ day of cyclosporine respectively. Thesmall alphabetic letters indicate a significant difference from (a) vehicle,(b) CYC10 and (c) CYC50 ( $<<0.05)$, as obtained by the Kruskal-Wallis H Test. Each zinc $(\mathrm{Zn})+\mathrm{CYC}$ treated group was compared with similar CYCalone treated group, without $\mathrm{Zn}$, using Mann-Whitney test. See the text for the treatment groups. 
Male

Female

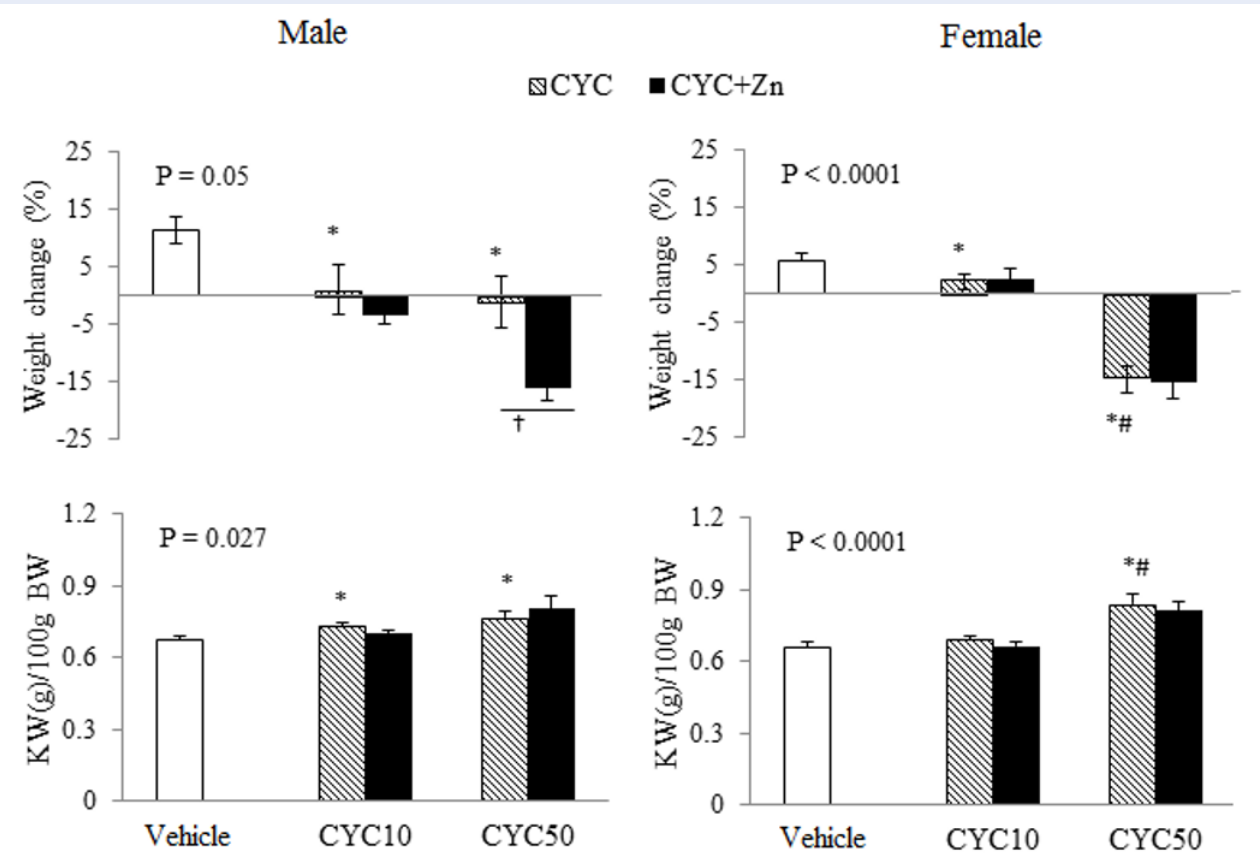

Figure 1: The weight percentage change and kidney weight (KW) per $100 \mathrm{~g}$ of body weight (BW) in surviving animals of the experimental groups. $\mathrm{CYC} 10$ and $\mathrm{CYC} 50$ indicate groups that were treated with cyclosporine (CYC)at $10 \mathrm{mg} / \mathrm{kg} /$ day and $50 \mathrm{mg} / \mathrm{kg} /$ day, respectively. The P-value was obtained by ANOVA among vehicle, CYC10 and CYC50 groups. The black bar shows CYC plus zinc (Zn)co-treated group. The symbols of * or \# indicate significant differences $(P<0.05)$ from vehicle or CYC10 groups, respectively, using LSD post hoc test; the symbol tindicates significant difference between CYC alone and CYC $+Z n$ co-treated group $(P<0.05)$ using Student's t-test.

normal in CYC $10(0.70 \pm 0.01 \mathrm{~g} / 100 \mathrm{~g} \mathrm{BW})$ or CYC $50(0.80 \pm 0.05 \mathrm{~g} /$

$100 \mathrm{~g} \mathrm{BW})$ groups. In female rats, the normalized KW in vehicle, CYC10, CYC50, CYC10+Zn, and CYC 50+Zn groups were $0.66 \pm 0.01,0.69 \pm 0.01$, $0.84 \pm 0.04,0.66 \pm 0.01$ and $0.81 \pm 0.03 \mathrm{~g} / 100 \mathrm{~g} \mathrm{BW}$, respectively. These findings indicated that the high dose of CYC (50 mg/kg/day) alone increased the normalized KW significantly $(\mathrm{P}<0.05)$, and that $\mathrm{Zn}$ supplement did not alter it.

\section{The serum levels of blood urea nitrogen} (BUN) and Creatinine (Cr)

In male rats, the levels of BUN in vehicle, CYC10, CYC50, CYC10+Zn and CYC50+Zn groups were $18.69 \pm 1.42, \quad 30.14 \pm 7.62, \quad 27.95 \pm 2.02, \quad 20.82 \pm 3.43$ and $39.81 \pm 11.31 \mathrm{mg} / \mathrm{dL}$, respectively, while the serum levels of $\mathrm{Cr}$ in these groups were $0.76 \pm 0.06$, $0.81 \pm 0.03, \quad 0.82 \pm 0.11, \quad 0.58 \pm 0.06$ and $0.69 \pm 0.08$ $\mathrm{mg} / \mathrm{dl}$. The serum levels of BUN/Cr ratio were also evaluated in male rats groups of vehicle; CYC10, CYC50, CYC10+Zn and CYC50+Zn were 25.88 \pm $3.04,37.94 \pm 9.84,37.92 \pm 6.79,36.01 \pm 4.07$ and $55.83 \pm 13.07$, respectively. The result indicated that the serum level of BUN, $\mathrm{Cr}$ and $\mathrm{BUN} / \mathrm{Cr}$ ratio increased insignificantly in male rats treated with CYC, and that $\mathrm{Zn}$ supplement decreased the serum levels of BUN insignificantly and $\mathrm{Cr}$ significantly $(\mathrm{P}<0.05)$ in low dose of CYC-treated rats (Figure 2, left panel). In female rats, the levels of BUN in vehicle, CYC10 and CYC 50, respectively, were $17.84 \pm 1.18$, $17.96 \pm 1.16$ and $35.37 \pm 9.83 \mathrm{mg} / \mathrm{dL}$. However, the $\mathrm{Zn}$ supplement did not attenuate these markers toward normal levels. The serum level of BUN in CYC $10+Z n$ and CYC50+Zn groups were $18.86 \pm 1.78$ and $53.73 \pm 10.11 \mathrm{mg} / \mathrm{dL}$, respectively (Figure 2, right panel). These results indicated that the CYC (50 $\mathrm{mg} / \mathrm{kg} /$ day) increased the serum levels of BUN and BUN/Cr ratio significantly $(\mathrm{P}<0.05)$ in females.

\section{Renal function parameters}

The findings related to renal function parameters were normalized to KW. The normalized UF in male rats for vehicle, CYC10, CYC50, CYC10+Zn and CYC50+Zn groups were $6.91 \pm 1.81,2.84 \pm 1.35$, $3.42 \pm 1.21,2.87 \pm 0.48$ and $4.74 \pm 0.62 \mu \mathrm{L} / \mathrm{min} / \mathrm{g}$ tissue, while the normalized $\mathrm{ClCr}$ in these groups were $465.90 \pm 120.29,249.19 \pm 54.09,305.27 \pm 90.80$, 
Male

Female

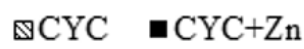
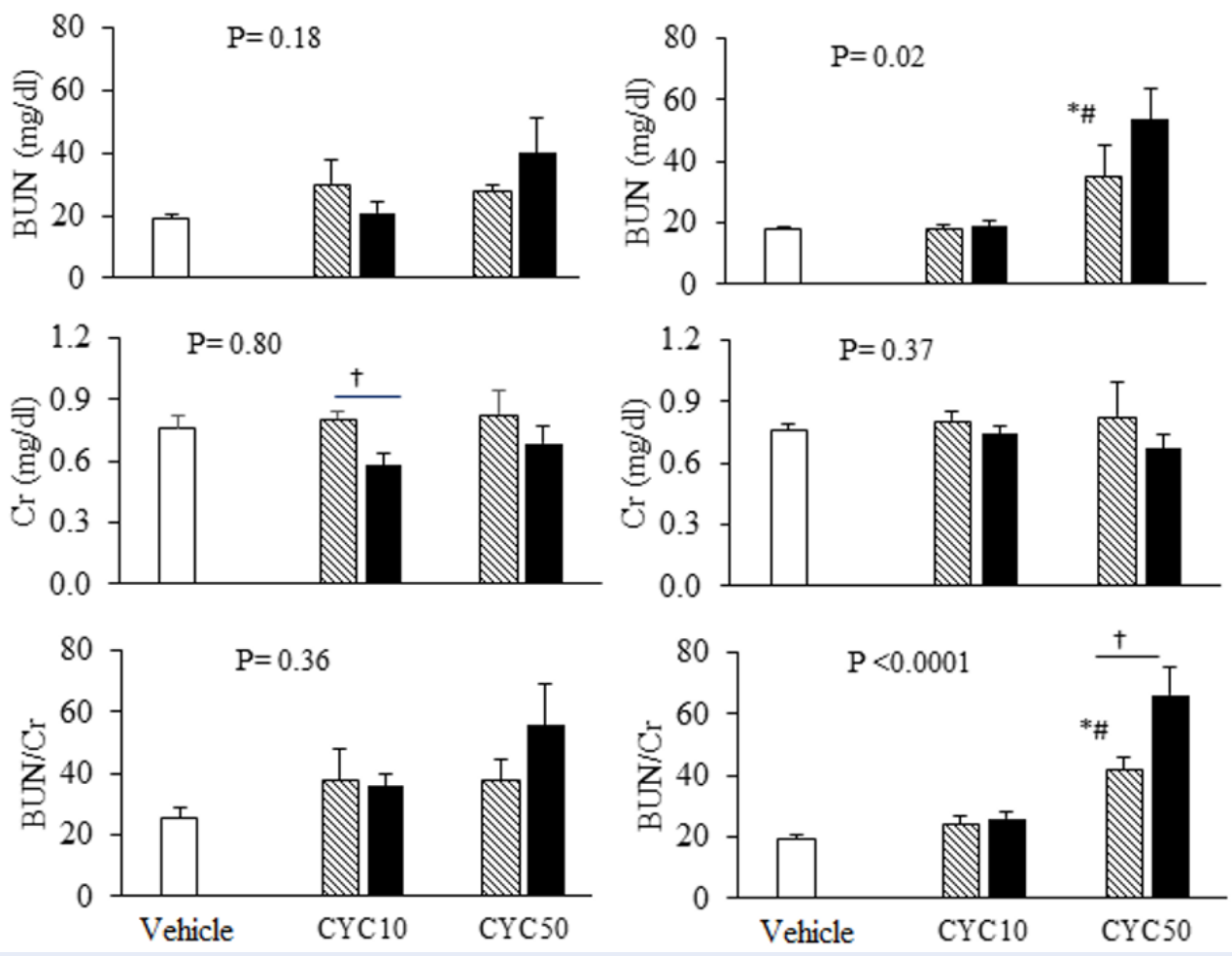

Figure 2: Serum levels of blood urea nitrogen (BUN), creatinine $(\mathrm{Cr})$ and $\mathrm{BUN} / \mathrm{Cr}$ ratio in surviving animals of the experimental groups. $\mathrm{CYC} 10$ and $\mathrm{CYC} 50$ represent the groups treated with cyclosporine (CYC) at a dose of $10 \mathrm{mg} / \mathrm{kg} /$ day or $50 \mathrm{mg} / \mathrm{kg} /$ day, respectively. The P-value was obtained by ANOVA among vehicle, CYC10 and CYC50 groups. The black bar shows CYC plus zinc (Zn) co-treated group. The symbols of * or \# indicate significant differences $(P<0.05)$ from vehicle or $C Y C 10$ groups, respectively, using LSD post hoc test. The symbol tindicates a significant difference between CYC alone and CYC $+Z n$ co-treated group $(P<0.05)$ using Student's t-test.

$460.82 \pm 107.20$ and $417.58 \pm 51.54 \mu \mathrm{L} / \mathrm{min} / \mathrm{g}$ tissue, respectively. The results revealed that CYC decreased $\mathrm{UF}$ and $\mathrm{ClCr}$ in male rats insignificantly.

The normalized UF in female rats for vehicle, CYC10, CYC50, CYC10+Zn and CYC50+Zn groups were $3.05 \pm 0.60,3.83 \pm 1.04,2.67 \pm 1.26,6.43 \pm 2.36$ and $3.89 \pm 1.78 \mu \mathrm{L} / \mathrm{min} / \mathrm{g}$ tissue, and the normalized $\mathrm{ClCr}$ in the mentioned groups were $201.01 \pm 33.10$, $366.03 \pm 50.18, \quad 138.63 \pm 74.82,435.75 \pm 100.60$ and $300.53 \pm 186.55 \mu \mathrm{L} / \mathrm{min} / \mathrm{g}$ tissue, respectively. These findings showed that CYC (at dose of $10 \mathrm{mg} / \mathrm{kg} /$ day) alone increased $\mathrm{ClCr}$ significantly in female rats when compared with vehicle group $(\mathrm{P}<0.05)$ (Figure 3$)$. However, Zn supplement did not provide the protective effect in either males or females.

In male rats, the normalized $\mathrm{Na}$ filtration rate in the vehicle, CYC10, CYC50, CYC10+Zn, and CYC50+Zn groups were $75.52 \pm 18.98,42.69 \pm 9.38,51.39 \pm 15.71$, $80.66 \pm 20.69,93.73 \pm 9.12 \mu \mathrm{moL} / \mathrm{min} / \mathrm{g}$ tissue, respectively, while the normalized $\mathrm{Na}$ excretion rate in these groups were $1.19 \pm 0.18,0.38 \pm 0.16,0.36 \pm 0.11$, $0.60 \pm 0.11,0.39 \pm 0.16 \mu \mathrm{mole} / \mathrm{min} / \mathrm{g}$ tissue and the percentage of $\mathrm{Na}$ excretion fraction were $1.96 \pm 0.29$, $0.72 \pm 0.19,0.72 \pm 0.16,0.88 \pm 0.21$ and $0.40 \pm 0.15 \%$, respectively. The results analyses indicated that the CYC alone decreased $\mathrm{Na}$ filtration rate (insignificantly), $\mathrm{Na}$ excretion rate, and percentage of $\mathrm{Na}$ excretion fraction (significantly, $\mathrm{P}<0.05$ ) in male rats (Figure 4, left panel).

Similar observation for the normalized $\mathrm{Na}$ excretion rate and percentage of $\mathrm{Na}$ excretion fraction were also observed in female rats (Figure 4, right panel). The normalized $\mathrm{Na}$ filtration rate for the vehicle, CYC10, CYC50, CYC10+Zn, CYC50+Zn female groups were 
Male

Female

$\triangle \mathrm{CYC} \quad \mathrm{CYC}+\mathrm{Zn}$
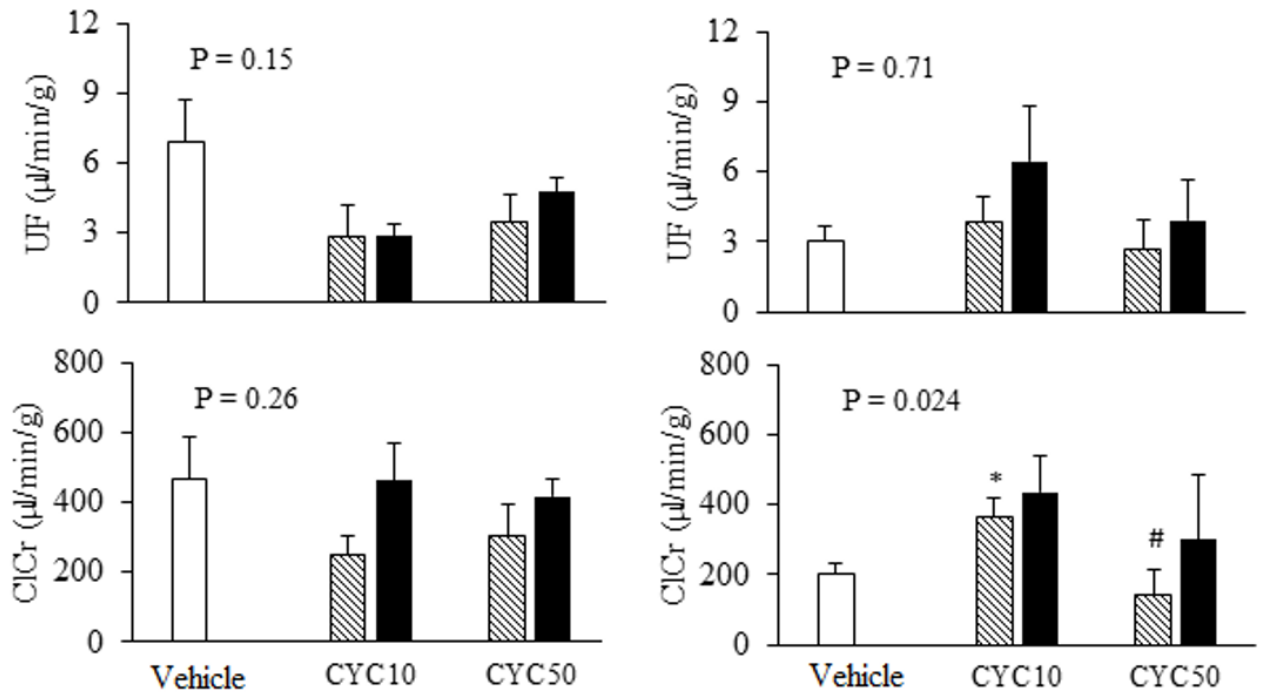

Figure 3: The urine flow (UF) and creatinine clearance ( $\mathrm{CICr}$ ) in surviving animals of the experimental groups. CYC10 and CYC50 represent the groups treated with cyclosporine (CYC) at a dose of $10 \mathrm{mg} / \mathrm{kg} /$ day or $50 \mathrm{mg} / \mathrm{kg} /$ day, respectively. The P-value was obtained by ANOVA among vehicle, CYC10 and CYC50 groups. The black bar shows CYC plus zinc ( $\mathrm{Zn})$ co-treated group. The symbols of * or \# indicate significant differences $(P<0.05)$ from vehicle or CYC10 groups, respectively, using LSD post hoc test. The symbol tindicates significant difference between CYC alone and CYC+Zn co-treated group $(P<0.05)$ using Student's t-test.

$34.19 \pm 5.27,67.31 \pm 9.82,24.72 \pm 13.44,77.43 \pm 18.55$, $51.20 \pm 31.60 \mu \mathrm{moL} / \mathrm{min} / \mathrm{g}$ tissue, while the $\mathrm{Na}$ excretion rate in these groups were $0.59 \pm 0.09,0.30 \pm 0.05$, $0.06 \pm 0.05,0.59 \pm 0.13,0.47 \pm 0.23 \mu \mathrm{moL} / \mathrm{min} / \mathrm{g}$ tissue, respectively. In the similar female rat groups, the percentage of $\mathrm{Na}$ excretion fractions were $1.81 \pm 0.28$, $0.46 \pm 0.07,0.25 \pm 0.08,0.85 \pm 0.11$, and $1.05 \pm 0.19 \%$, respectively. As the data show, the $\mathrm{Zn}$ supplement increased the $\mathrm{Na}$ excretion rate and the percentage of $\mathrm{Na}$ excretion fraction, only in female rats.

\section{The kidney histology findings}

In the male rats, the mean value of KTDS for vehicle, CYC10, CYC50, CYC100, CYC10+Zn and $\mathrm{CYC} 50+\mathrm{Zn}, \mathrm{CYC} 100+\mathrm{Zn}$ groups were $0.5 \pm 0.18$, $1.37 \pm 0.18,1.75 \pm 0.16,2.42 \pm 0.20,0.66 \pm 0.21,2 \pm$ $0.18,2.7 \pm 0.18$, while in the female gender of above groups these findings were $0.5 \pm 0.18,1.62 \pm 0.26$, $2 \pm 0.20,2.71 \pm 0.18,1 \pm 0.18,2.25 \pm 0.26,2.83 \pm 0.16$, respectively. The histology data indicated that KTDS was increased by CYC dose dependently of both male and female rats (Figure 5). Hence, $\mathrm{Zn}$ supplement decreased the KTDS in male and female rats treated with CYC $(10 \mathrm{mg} / \mathrm{kg} /$ day $)$ significantly $(\mathrm{P}<0.05)$. The samples of images from the animals in each group of experiment are shown in Figure 6.

\section{DISCUSSION}

The major findings of this study indicated that CYCinduced nephrotoxicity was dose-related in both male and female rats. In addition, $\mathrm{Zn}$ supplementation accompanied with low dose of CYC (10 mg/kg/day) attenuated CYC and induced tissue damage. The protective role of $\mathrm{Zn}$ in male rats treated with low dose of CYC (10 mg/kg/day) also was observed by attenuation of serum level of Cr. In addition, when UF, $\mathrm{ClCr}, \mathrm{Na}$ filtration rate, $\mathrm{Na}$ excretion rate and $\mathrm{Na}$ excretion fraction are considered, the data indicated that low dose of CYC accompanied with $\mathrm{Zn}$ increased all the mentioned markers insignificantly. On the contrary, when KW and body weight change were targeted, Zn supplementation with low dose of CYC did not alter weight loss and KW. Finally, if pathological findings are looked as ultimate findings, the interpretation of the data will be easier, and we can assumed that $\mathrm{Zn}$ could be a protectant agent against CYC (10 mg/kg/day) induced nephrotoxicity. CYC 


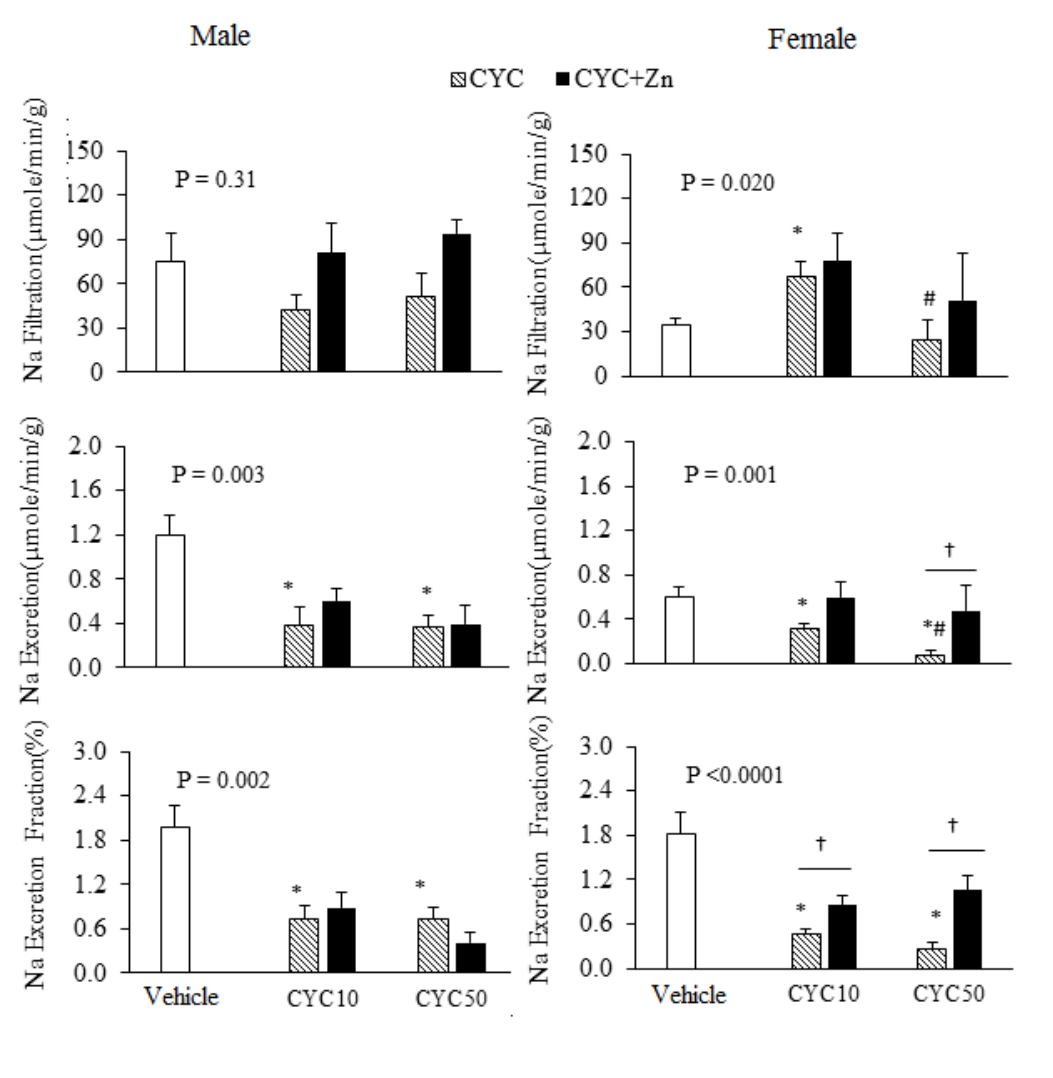

Figure 4: The sodium ( $\mathrm{Na}$ ) filtration rate, $\mathrm{Na}$ excretion rate and $\mathrm{Na}$ excretion fraction (\%) in surviving animals of the experimental groups. CYC10 and CYC50 represent the groups treated with cyclosporine (CYC) at 10 $\mathrm{mg} / \mathrm{kg} / \mathrm{day}$ or $50 \mathrm{mg} / \mathrm{kg} /$ day dose, respectively. The P-value was obtained by ANOVA among vehicle,CYC10 and CYC50 groups. The black bar shows CYC plus zinc (Zn) co-treated group. The symbols of * or \# indicate significant differences $(P<0.05)$ from vehicle or CYC10 groups, respectively, using LSD post hoc test. The symbol tindicates a significant difference between $C Y C$ alone and $C Y C+Z n$ co-treated group $(P<0.05)$ using Student's t-test.

reduced the body weight percentage change and increased the normalized KW. The weight gain by CYC was reported before ${ }^{43}$. Under conditions of induced nephrotoxicity, both body weight loss and KW gain occurred $^{25-27}$. Together with BUN, Cr and BUN/Cr ratio data, it seems that weight loss and $\mathrm{KW}$ gain are related to CYC induced nephrotoxicity, which are confirmed by pathology findings. The weight loss and $\mathrm{KW}$ gain by CYC $(50 \mathrm{mg} / \mathrm{kg}$ ) was different in female rats; this difference may be related to body water content. Male and female rats have different distribution of body fluid compartment, and this fact may affect the alteration of markers, such as body weight loss, KW gain and the serum level of BUN. In addition, $\mathrm{Zn}$ supplementation decreases the serum levels of BUN and $\mathrm{Cr}$ in male rats treated with low dose of CYC (10 $\mathrm{mg} / \mathrm{kg} /$ day) when compared with CYC alone treated rats (Figure 2). Such observation was not detected in female. The protective effect of $\mathrm{Zn}$ in kidney injury may be dose and gender related ${ }^{34,39}$, and actually the involved mechanisms is not well clear. Some of the renal function markers also were different between genders. Collectively, this difference possibly is related to sex hormones. CYC affects sex hormones ${ }^{44,45}$, and invitro study demonstrated that the therapeutic dose of CYC may alter ovarian function ${ }^{45}$. The $\mathrm{Zn}$ also may protect the kidney gender dependently ${ }^{39}$. Therefore, the different responses from the measured markers to $\mathrm{CYC}$ and $\mathrm{Zn}$ in male and female rats may be expected, but the exact mechanisms need to be defined. There is one limitation in our study related to dose of $\mathrm{Zn}$. In the current study, we only used $10 \mathrm{mg} / \mathrm{kg} /$ day of Zn sulphate, and possibly this dose of $\mathrm{Zn}$ supplement may be appropriate for a lower dose of CYC. A higher dose of CYC ( $50 \mathrm{mg} / \mathrm{kg} /$ day) needs higher doses of $\mathrm{Zn}$ sulphate. 
Male

Female
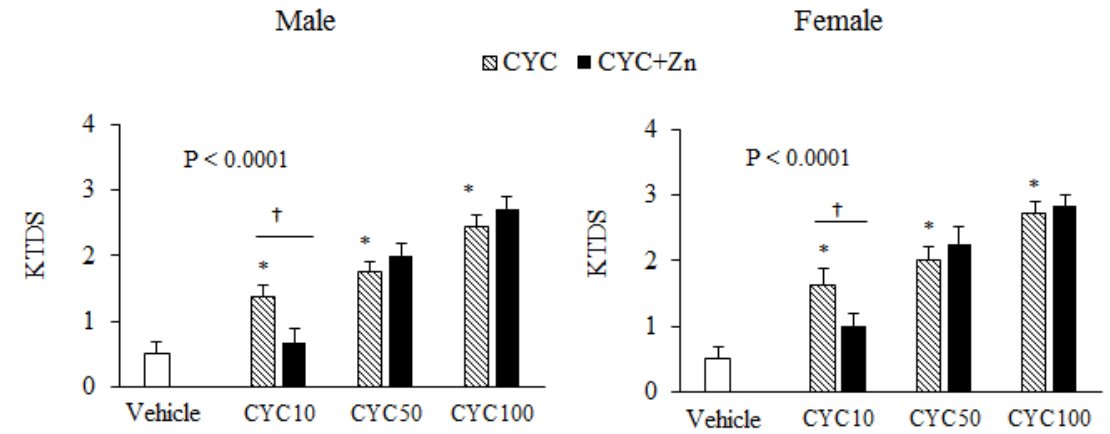

Figure 5: The kidney tissue damage score (KTDS) for the entire experimental groups. CYC10, CYC50 and CYC100 indicate the groups treated with cyclosporine (CYC) at a dose of $10 \mathrm{mg} / \mathrm{kg} / \mathrm{day}, 50 \mathrm{mg} / \mathrm{kg} / \mathrm{day}$, or 100 $\mathrm{mg} / \mathrm{kg} / \mathrm{day}$, respectively. The P-value was obtained by Kruskal-Wallis $\mathrm{H}$ Test. The co-treatment of zinc ( $\mathrm{Zn}$ ) and CYC groups were compared to that of CYC alone with or without the treated group, using Mann Whitney Test. The black bar shows $C Y C+Z n$ treated group. The symbols of * or \# indicate significant differences $(P<0.05)$ from vehicle or CYC10 groups respectively using Mann Whitney Test, and the symbol tindicates significant difference between CYC alone and $C Y C+Z n$ treated group $(P<0.05)$.

\section{CONCLUSIONS}

The high dose of CYC $(100 \mathrm{mg} / \mathrm{kg})$ demonstrated the highly toxic effect. No animals survived on the last day of experiment, and the other dose of CYC induced nephrotoxicity gender dependently. However, the 10 $\mathrm{mg} / \mathrm{kg}$ of $\mathrm{Zn}$ sulphate as a supplement may prevent induced nephrotoxicity in males, possibly due to its antioxidant effects.

\section{COMPETING INTERESTS}

The authors have declared that no conflict of interest exists

\section{AUTHORS' CONTRIBUTIONS}

SC, SK and AT conducted the experimental procedures and data analysis, MM, YG, and MM conducted study design, and finalized the article. MN conducted study design, experimental procedures, data analysis and finalized the article.

\section{ACKNOWLEDGEMENTS}

This research was supported by Isfahan University of Medical Sciences. The authors express their thanks to Zahravi Pharm Co (Tabriz, Iran) for providing of Ciclosporin.

\section{REFERENCES}

1. Sharma A, Jain S, Gupta R, Guleria S, Agarwal S, Dinda A. Calcineurin inhibitor toxicity in renal allografts: morphologic clues from protocol biopsies. Indian Journal of Pathology \& Microbiology. 2010;53:651-7. Available from: Doi:10.4103/ 0377-4929.72015.
2. Kokuhu T, Fukushima K, Ushigome H, Yoshimura N, Sugioka N. Dose adjustment strategy of cyclosporine $A$ in renal transplant patients: evaluation of anthropometric parameters for dose adjustment and C0 vs. C2 monitoring in Japan, 2001-2010. International Journal of Medical Sciences. 2013;10:1665-73. Available from: DOI:10.7150/ijms.6727.

3. Aziz MM, Eid NI, Nada AS, Amin NE, Ain-Shoka AA. Possible protective effect of the algae spirulina against nephrotoxicity induced by cyclosporine $\mathrm{A}$ and/or gamma radiation in rats. Environmental Science and Pollution Research International. 2018;25:9060-70. Available from: DOI:10.1007/s11356-0171146-0.

4. Mostafa-Hedeab G, Sati LM, Elnaggar HM, Elgatlawey ZO, Eltwab AA, Elsaghayer WA. Ameliorating effect of olive leaf extract on cyclosporine-induced nephrotoxicity in rats. Iranian Journal of Kidney Diseases. 2015;9:361-8.

5. Shin BC, Kwon YE, Chung JH, Kim HL. The antiproteinuric effects of green tea extract on acute cyclosporine-induced nephrotoxicity in rats. Transplant Proc. 2012;44:1080-2.

6. Caires A, Fernandes GS, Leme AM, Castino B, Pessoa EA, Fernandes SM. Endothelin-1 receptor antagonists protect the kidney against the nephrotoxicity induced by cyclosporine$A$ in normotensive and hypertensive rats. Brazilian Journal of Medical and Biological Research. 2017;51:e6373. Available from: DOI:10.1590/1414-431x20176373.

7. Raeisi S, Ghorbanihaghjo A, Argani H, Dastmalchi S, Ghasemi $B$, Ghazizadeh T. The effects of valsartan on renal glutathione peroxidase expression in alleviation of cyclosporine nephrotoxicity in rats. Biolmpacts. 2016;6:119-24. Available from: DOI:10.15171/bi.2016.18.

8. Hewedy WA, Mostafa DK. Nebivolol suppresses asymmetric dimethylarginine and attenuates cyclosporine-induced nephrotoxicity and endothelial dysfunction in rats. Pharmacological Reports. 2016;68:1319-25. Available from: DOI: 10.1016/j.pharep.2016.08.009.

9. El-Gowilly SM. Metoprolol ameliorates cyclosporine ainduced hypertension and nephrotoxicity in rats. Journal of Cardiovascular Pharmacology. 2011;58:639-46. Available from: DOI:10.1097/FJC.0b013e318231166f. 

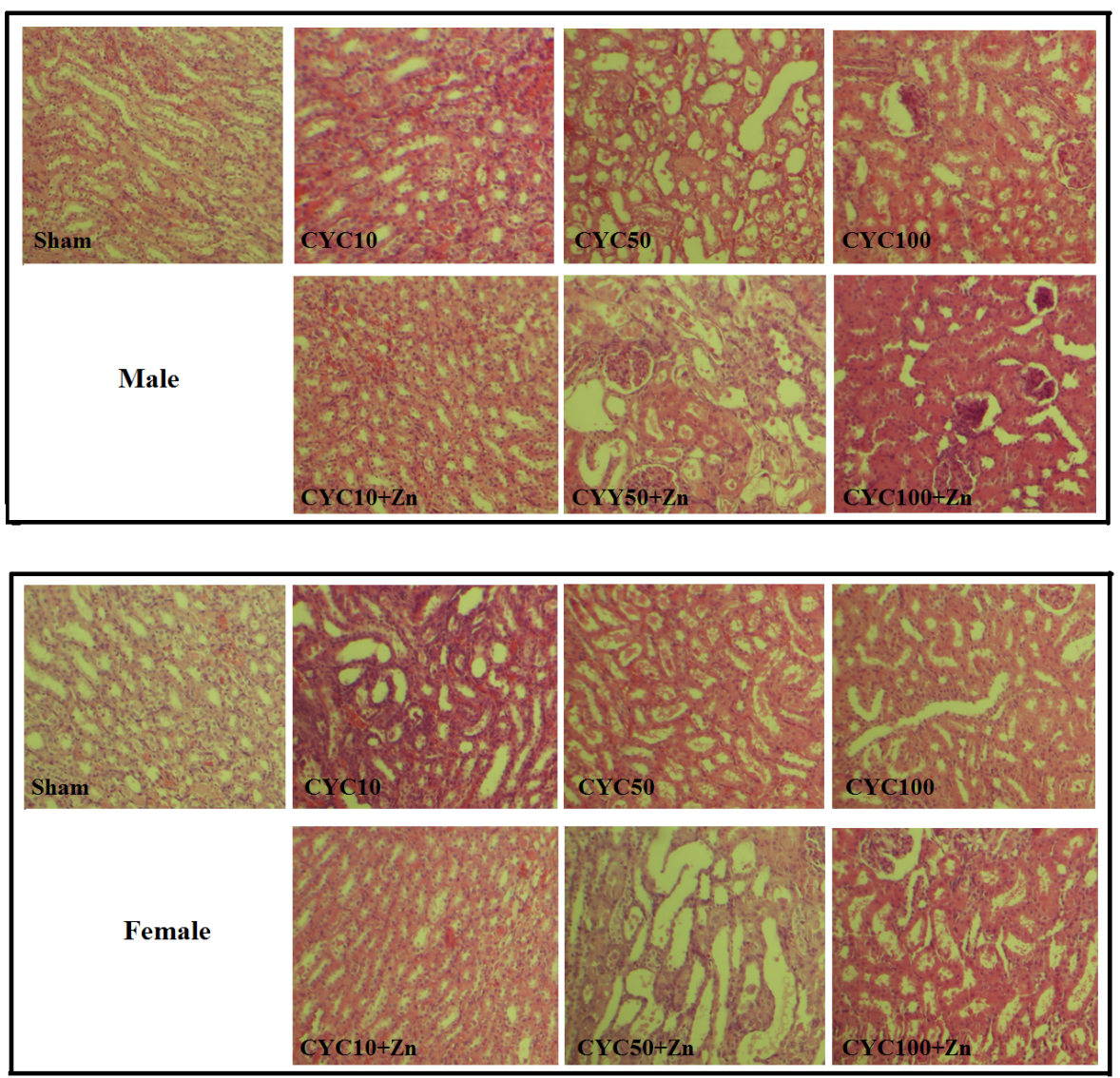

Figure 6: The kidney tissue images with magnification of 100X. The $C Y C 10, C Y C 50$ and $C Y C 100$ represent the groups treated with cyclosporine $(10 \mathrm{mg} / \mathrm{kg} /$ day, $50 \mathrm{mg} / \mathrm{kg} / \mathrm{day}$ and $100 \mathrm{mg} / \mathrm{kg} /$ day, respectively). The CYC10 $\mathrm{Zn}$, CYC50+Zn and CYC100+Zn indicate the groups treated with cyclosporine (CYC: $10 \mathrm{mg} / \mathrm{kg}, 50 \mathrm{mg} / \mathrm{kg}$ and 100 $\mathrm{mg} / \mathrm{kg}$ plus $10 \mathrm{mg} / \mathrm{kg}$ ) and of zinc ( $\mathrm{Zn}$ ) sulfate, respectively.

10. Ciarcia R, Damiano S, Florio A, Spagnuolo M, Zacchia E, Squillacioti C. The Protective Effect of Apocynin on Cyclosporine A-Induced Hypertension and Nephrotoxicity in Rats. Journal of Cellular Biochemistry. 2015;116:1848-56. Available from: DOI: $10.1002 /$ jcb. 25140 .

11. Al-Malki AL, Moselhy SS. The protective effect of epicatchin against oxidative stress and nephrotoxicity in rats induced by cyclosporine. Human and Experimental Toxicology. 2011;30:145-51. Available from: Doi:10.1177/ 0960327110369820.

12. Mariee AD, Abd-Ellah MF. Protective effect of docosahexaenoic acid against cyclosporine A-induced nephrotoxicity in rats: a possible mechanism of action. Renal Failure. 2011;33:66-71. Available from: Doi:10.3109/0886022x.2010. 541584.

13. Kim JS, Yang JW, Han BG, Kwon HJ, Kim JH, Choi SO. Protective Role of Apelin Against Cyclosporine-Induced Renal Tubular Injury in Rats. Transplant Proc. 2017:49:1499-1509.

14. Saraswat MS, Addepalli V, Jain M, Pawar VD, Patel RB. Renoprotective activity of aliskiren, a renin inhibitor in cyclosporine A induced hypertensive nephropathy in dTG mice. Pharmacological Reports. 2014;66:62-7. Available from: DOI:10.1016/j. pharep.2013.08.005.

15. Tornatore KM, Brazeau D, Dole K, Danison R, Wilding G, Leca N
Sex differences in cyclosporine pharmacokinetics and $A B C B 1$ gene expression in mononuclear blood cells in African American and Caucasian renal transplant recipients. Journal of Clinical Pharmacology. 2013;53:1039-47. Available from: DOI: 10.1002/jcph.123.

16. Gottschalk S, Cummins CL, Leibfritz D, Christians U, Benet LZ Serkova NJ. Age and sex differences in the effects of the immunosuppressants cyclosporine, sirolimus and everolimus on rat brain metabolism. Neurotoxicology. 2011;32:50-7. Available from: DOI:10.1016/j.neuro.2010.10.006.

17. Muller V, Szabo AJ, Erdely A, Tain YL, Baylis C. Sex differences in response to cyclosporine immunosuppression in experimental kidney transplantation. Clinical and Experimental Pharmacology \& Physiology. 2008;35:574-9. Available from: DOI:10.1111/j.1440-1681.2007.04841.x.

18. Hirasawa K, Kamada N. Female sex hormone, estradiol, antag onizes the immunosuppressive activity of cyclosporine in rat organ transplantation. Transplant Proc. 1992;24:408-9.

19. Robson SC, Neuberger JM, Williams R. The influence of cyclosporine A therapy on sex hormone levels in pre- and postmenopausal women with primary biliary cirrhosis. Journal of Hepatology. 1994;21:412-6. Available from: Doi:10.1016/ s0168-8278(05)80321-6.

20. Kramer BK, Neumayer HH, Stahl R, Pietrzyk M, Kruger B, Pfalze 
B, et al. Graft function, cardiovascular risk factors, and sex hormones in renal transplant recipients on an immunosuppressive regimen of everolimus, reduced dose of cyclosporine, and basiliximab. Transplant Proc. 2005;37:1601-4.

21. Dh VT. RS, JS G, A F. Hepatic regeneration. Digestive Diseases and Sciences. 1991;36:1309-12.

22. El-Bassossy HM, Eid BG. Cyclosporine A exhibits genderspecific nephrotoxicity in rats: effect on renal tissue inflammation. Biochemical and Biophysical Research Communications. 2018;495:468-72. Available from: DOI:10.1016/j.bbrc.2017.11. 042.

23. El-Bassossy HM, Awan Z, El-Mas MM. Perinatal ciclosporin A exposure elicits sex-related cardiac dysfunction and inflammation in the rat progeny. Toxicology Letters. 2017;281:3543. Available from: DOI:10.1016/j.toxlet.2017.09.002.

24. Nematbakhsh M, Pezeshki Z, Jazi FE, Mazaheri B, Moeini M, Safari $T$, et al. Cisplatin-induced nephrotoxicity; protective supplements and gender differences. Asian Pacific journal of cancer prevention: APJCP. 2017;18:295.

25. Nematbakhsh M, Ebrahimian S, Tooyserkani M, Eshraghi-Jazi F, Talebi A, Ashrafi F. Gender difference in Cisplatin-induced nephrotoxicity in a rat model: greater intensity of damage in male than female. Nephro-Urology Monthly. 2013;5:818-21. Available from: DOI:10.5812/numonthly.10128.

26. Eshraghi-Jazi F, Nematbakhsh M, Nasri H, Talebi A, Haghighi $M$, Pezeshki $Z$, et al. The protective role of endogenous nitric oxide donor (L-arginine) in cisplatin-induced nephrotoxicity: Gender related differences in rat model. J Res Med Sci. 2011;16:1389-96.

27. Haghighi M, Nematbakhsh M, Talebi A, Nasri H, Ashrafi F, Roshanaei K. The role of angiotensin II receptor 1 (AT1) blockade in cisplatin-induced nephrotoxicity in rats: genderrelated differences. Renal Failure. 2012;34:1046-51. Available from: Doi:10.3109/0886022x.2012.700886.

28. Eshraghi-Jazi F, Talebi A, Mirsaeedi FS, Ahmadian S, Moslemi F, Nematbakhsh M. Gentamicin Induced Nephrotoxicity: The Role of Sex Hormones in Gonadectomized Male and Female Rats. Scientifica. 2016;5025097:26.

29. Chen WY, Hsiao CH, Chen YC, Ho CH, Wang JJ, Hsing CH. Cisplatin Nephrotoxicity Might Have a Sex Difference. An analysis Based on Womenś Sex Hormone Changes. Journal of Cancer. 2017;8:3939-44. Available from: DOI:10.7150/jca.20083.

30. Eshraghi-Jazi F, Nematbakhsh M, Pezeshki Z, Nasri H, Talebi A, Safari T. Sex differences in protective effect of recombinant human erythropoietin against cisplatin-induced nephrotoxicity in rats. Iranian Journal of Kidney Diseases. 2013;7:383-9.

31. Pezeshki Z, Nematbakhsh M, Nasri H, Talebi A, Pilehvarian AA, Safari T. Evidence against protective role of sex hormone estrogen in Cisplatin-induced nephrotoxicity in ovarectomized rat model. Toxicology International. 2013;20:43-7. Available from: Doi:10.4103/0971-6580.111568.

32. Nematbakhsh M, Nasri H. Cisplatin nephrotoxicity may be sex related. Kidney International. 2013;83:1201. Available from: DOI:10.1038/ki.2013.37.
33. Wongtawatchai T, Agthong S, Kaewsema A, Chentanez V. Sexrelated differences in cisplatin-induced neuropathy in rats. Journal of the Medical Association of Thailand. 2009;92:148591.

34. Rao K, Sethi K, Ischia J, Gibson L, Galea L, Xiao L. Protective effect of zinc preconditioning against renal ischemia reperfusion injury is dose dependent. PLoS One. 2017;12:e0180028. Available from: DOI:10.1371/journal.pone.0180028.

35. Xu Z, Zhou J. Zinc and myocardial ischemia/reperfusion injury. Biometals. 2013;26:863-78. Available from: DOI:10 1007/s10534-013-9671-x

36. Shuttleworth $\mathrm{CW}$, Weiss JH. Zinc: new clues to diverse roles in brain ischemia. Trends in Pharmacological Sciences. 2011;32:480-6. Available from: DOI:10.1016/j.tips.2011.04 001.

37. Ogawa T, Mimura Y. Antioxidant effect of zinc on acute renal failure induced by ischemia-reperfusion injury in rats. American Journal of Nephrology. 1999;19:609-14. Available from: Doi:10.1159/000013529.

38. Guo L, Li P, Meng C, Lu R, Yang Y, Zhou Y. Protective effect of zinc on mouse renal ischemia-reperfusion injury by anti-apoptosis and antioxidation. Current Pharmaceutical Biotechnology. 2014;15:577-82. Available from: Doi:10.2174/ 1389201015666140827110120.

39. Moslemi F, Talebi AM. The protective effect of zinc supplementation on renal ischemia/reperfusion injury in rat: gender-related difference. International Journal of Preventive Medicine. 2018.

40. Yilmaz M, Mogulkoc R, Baltaci AK. Effect of Three-Week Zinc and Melatonin Supplementation on the Oxidant-Antioxidant System in Experimental Renal Ischemia-Reperfusion in Rats. Acta Clinica Croatica. 2015:54:395-401.

41. Guo L, Li P, Meng C, Lu R, Yang Y, Zhou Y. Protective ef fect of zinc on mouse renal ischemia-reperfusion injury by anti-apoptosis and antioxidation. Current Pharmaceutical Biotechnology. 2014;15:577-82. Available from: Doi:10.2174/ 1389201015666140827110120.

42. Barekat F, Talebi AM. The protective roles of zinc and estradio in renal ischemia/ reperfusion injury in ovariectomized rats. Journal of Nephropathology. 2018;7:5.

43. Ersoy A, Baran B, Ersoy C, Kahvecioglu S, Akdag I. Calcineurin inhibitors and post-transplant weight gain. Nephrology (Carlton, Vic). 2008;13:433-9. Available from: DOI:10.1111/j.14401797.2008.00916.x.

44. Robson SC, Neuberger JM, Williams R. The influence of cyclosporine $A$ therapy on sex hormone levels in pre- and postmenopausal women with primary biliary cirrhosis. Journal of Hepatology. 1994:21:412-6. Available from: Doi:10.1016/ s0168-8278(05)80321-6.

45. Gore-Langton RE. Cyclosporine differentially affects estrogen and progestin synthesis by rat granulosa cells in vitro. Molecular and Cellular Endocrinology. 1988:57:187-98. Available from: Doi:10.1016/0303-7207(88)90074-3. 